\title{
The Effect of Mathematical Resilience and Students' Perceptions of Online Lectures on Mathematical Power
}

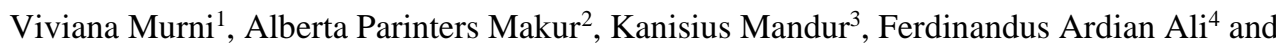 \\ Polikarpus Raga ${ }^{5}$ \\ \{vivianamurni0123@gmail.com ${ }^{1}$ \}
}

Unika Santu Paulus Ruteng, NTT, Indonesia ${ }^{12345}$

\begin{abstract}
This study aimed to determine simultaneously and partially the effect of mathematical resilience and students' perceptions of online lectures on the mathematical power of students of the mathematics education study program, Unika Santu Paulus Ruteng. This research used an ex post facto approach. The population in this study were all first-years students of the mathematics education study program Unika Santu Paulus Ruteng. The sampling technique in this study was simple random sampling, so the sample was 30 students. The data were collected by questionnaires and tests. The questionnaire was used to collect data on mathematical resilience and student perceptions about online lectures, while the test was used to collect data on students' mathematical power. Data were analyzed by multiple linear regression. The linear equation obtained was $\mathrm{Y}=20.233+0.498 \mathrm{X} 1+0.227 \mathrm{X} 2$, so the results showed that there was a simultaneous and partial effect on mathematical resilience and perceptions of online lectures on students' mathematical power.
\end{abstract}

Keywords: Mathematical Resilience; Perceptions of Online Lectures; Mathematical Power

\section{Introduction}

Advances in science and technology can provide online lectures solutions to learning that are applied during the Covid-19 pandemic. The application of online lectures requires lecturers and students to adapt to the lecture process that will be undertaken, without considering the obstacles they face. Whatever difficulties they face, students must accept the reality to take full course online lectures and of the course, students will experience problems in certain ways. Therefore, resilience is needed for students, because students with high resilience will survive and be able to find solutions to problems or difficulties faced during the Covid-19 pandemic [1] [2] also stated that good resilience can help students in carrying out tri dharma tertiary activities.

In addition, [3] stated that students with high resilience will be more optimistic and believe that everything will be fine. Likewise, it relates to mathematical resilience, namely the positive attitude of students in mathematics courses, which includes being diligent in solving mathematics learning difficulties and considers mathematics to be more than what is learned in class. [4] stated that mathematical resilience is very necessary for students to think mathematically and behave mathematically, not just to get good grades. 
Besides students having to adapt to online lectures, students of course have different perceptions of online lectures. Perceptions of online lectures include students' perceptions in the learning process, students' perceptions of the capabilities of lecturers, and students' perceptions of using facilities and infrastructure [5]. This is caused by various things, such as heterogeneous student abilities, students family background, mindset, experience, and student's character. Students who have good abilities and are financially capable of course have the perception that online lectures do not have an impact on learning difficulties and even students think that online lectures will be an opportunity to profit more creatively and become a motivation to learn many things.

On the other hand, students with low abilities will have difficulty adapting to online lectures. Apart from the ability factor, complete facilities and financial ability also determine students' perceptions of online lectures. There is also [6], the results of his research show that online lectures have a positive impact on aspects of connectedness, aspects of learning, and social aspects.

Thus, mathematical resilience and students 'perceptions of online lectures have an affect student' mathematical power. [7] stated that mathematical power includes problem-solving abilities, mathematical communication, connections, reasoning, and mathematical representations of students. This study aims to determine the effect of students' perceptions and resilience about online lectures on mathematical power.

\subsection{Mathematical Resilience}

Learning mathematics is a teaching and learning process that contains teaching and learning activities. In these two activities, there is an interaction between students and educators, so that the two are expected to support each other so that the mathematics learning process can run well and the expected learning objectives can be achieved well. The supporting factor so that the learning objectives run well is the positive attitude of students in participating in learning. The learning attitude is referred to as resilience. Resilience to mathematics is often called mathematical resilience. Mathematical resilience includes being persistent or persistent in the face of collaborative learning difficulties with peers and having language skills to express mathematical understanding [8]. Resilience plays an important role in learning mathematics.

Therefore, according to [9] mathematical resilience is a very important concept in education because there are still so many students who experience difficulties and failures in learning mathematics. Students who have mathematical resilience, these students can foster confidence in themselves. They consider that mathematics is not an obstacle, even when the student himself experiences difficulties, he will maintain his confidence until it ends successfully. He will not hesitate to help his friends/groups based on the knowledge they have, can take advantage of his friends' help and support if needed. Thus, students who have mathematical resilience can solve mathematical problems in any form.

Mathematical resilience is also needed by teachers to educate students to use mathematics and to think and behave mathematically and not just to get good grades or pass math exams. Students with strong resilience, in addition to having the mathematical skills needed to answer questions on the exam, also have the necessary mathematical skills anytime and anywhere. The development of mathematical resilience also requires a reflective and sensitive attitude towards learning mathematics.

According to [5], several indicators of mathematical resilience are;

a. Having the belief that mathematics is something valuable and worthy of being pursued and studied. The behavior of mathematical resilience students has in-depth knowledge of 
mathematics which they have helped to understand and learn more complex topics, states that mathematics is very important for life, and they can also express that they can see the importance of mathematics being pursued and studied to provide values. Which is good for an individual student, including in terms of supporting careers.

b. Have the willingness and persistence in studying mathematics, despite experiencing difficulties, obstacles, and challenges. The behavior of students' mathematical resilience by showing the attitude of trying hard when facing difficult mathematical problems, behavior when making mistakes when studying mathematics and correcting the mistakes made, showing the attitude of having the possibility of failing a difficult math test, as well as the responses they give when a math teacher who is confused by math problems.

c. Having confidence in yourself that you can learn mathematics, based on an understanding of mathematics, the ability to create strategies, the help of tools and other people, and also the experience that is built. Students' mathematical resilience behavior is shown by trying to keep trying when learning mathematics, showing the attitude that everyone has the same ability to learn mathematics, and solve mathematical problems.

d. Has a defensive nature, never gives up, and always gives a positive response in learning mathematics? Students' mathematical resilience behavior by showing that they have a strategy to use when experiencing deadlock while trying to solve mathematical problems. When experiencing obstacles when solving mathematical problems, they immediately seek/ask for help from others, the attitude shown when the assignment or math test is not as expected, meaning that only the ability they have, as well as the opinion given to a statement which says that the result math assignment or test is a reflection of ability in mathematics.

Based on these indicators, it is concluded that several indicators make a questionnaire to determine students' interest in learning, namely; (1) have the belief that mathematics is something valuable and worthy of being pursued and studied; (2) have the willingness and persistence in studying mathematics, despite experiencing difficulties, obstacles, and challenges; (3) having confidence in oneself that they can learn mathematics, based on an understanding of mathematics, the ability to create strategies, help with tools and other people, and also build experiences; (4) has a defensive nature, never gives up, and always gives a positive response in learning mathematics.

\subsection{Perceptions of Online Lectures}

According to [10], perception is a person's tendency to be relative, individual perceptions of something will vary based on the perceptions of each person. Furthermore, [11] states that perception is related to how to obtain knowledge about a certain object which causes the perception of each person to be different because they have different points of view. It can be concluded that perception is an activity of interpreting the stimulus based on sensory absorption of the object encountered. Perception will encourage students to be smart in managing everything in online lectures. Students are expected to balance academic life and personal life so that they can increase their academic and non-academic achievements during the Covid-19 pandemic.

Then, lectures/learning can be called blended learning, which is learning that combines the advantages of face-to-face learning and e-learning [12] [13]. In online learning, many applications can be used such as zoom, Moodle, Whatsapp, Google Classroom, YouTube, google meet, and others [12]. [12] stated that the increase in the role and activeness of students in using technology in supporting success in lectures is strongly influenced by perceptions. 
So, students 'perceptions about online lectures are students' thoughts or responses about the implementation of online lectures based on their inherent abilities and characteristics.

\subsection{Mathematical Power}

According to [14], mathematical power is something related to the ability needed by a person to explore, predict, and reason logically, as well as the ability to use mathematical methods in solving non-routine mathematical problems. This is based on the fact that mathematics is more of a set of concepts and skills that must be mastered, including methods of investigation and reasoning, communication tools, and understanding of context. Apart from that, mathematical power also involves developing the self-confidence of each individual. In other words, mathematical power is a person's ability to solve mathematical problems, reason mathematically, connect what is learned with other topics in mathematics, with other disciplines, and with everyday life, and appreciate the value and beauty of mathematics.

Furthermore, [15] the power of mathematics is defined as the strength of mathematics. Students can gain awareness of the importance of strengths or mathematical styles through meaningful learning provided by the teacher. Mathematical strengths, including the ability to (1) assess, predict, and reason logically, (2) solve irregular problems, (3) communicate about and through mathematics, (4) link ideas in mathematical ideas and between mathematics and other intellectual activities, (5) develop self-confidence, character or character to seek, evaluate, and use specific quantitative information and solve problems and make decisions.

So, it is concluded that the power of mathematics is a positive energy that comes from someone who is studying mathematics so that there are continuous challenges (through activities: assessing, suspecting, logical reasoning), motivation, fun, curiosity, which is actualized through the ability to solve problems and communicate mathematics in everyday life. Things that increase awareness of the power of mathematics are persistence, persistence, effort, motivation, interest, curiosity, and creativity.

Broadly speaking, the power or mathematical power contains the following values: 1) The results and results of power-play affect how individuals learn to acquire knowledge, skills, and attitudes which will be reflected in daily behavior, 2) The power of mathematics plays a very important role in developing trust. self, critical thinking, reasoning, character or character to seek, evaluate, communicate, and use quantitative and special information in solving problems and making decisions, 3) Mathematical power can turn difficulties into challenges as a form of self-satisfaction, 4) The power of mathematics also functions to motivate, stimulate appreciation of the complexity of student success in interdisciplinary learning.

Several previous studies on the variables in this study, but no research is the same as the title of this study. Some of these studies are as follows: (1) research conducted by [16] with the title of research on mathematics education students' perceptions of online learning during the learn from home (LFH) period of the Covid-19 pandemic, the results of the study show that students use more online learning. 49 respondents used the WhatsApp application and 35 respondents used google classroom and 12 other applications, 4 respondents at zoom, and 3 respondents on google meet.

The student response to the statement "online learning makes the lecture process more organized", shows that $48 \%$ disagree and those who say "Enough agree" are 36\%, etc. with the findings of suggestions from several students who stated the need to carry out a joint evaluation, either lecturers or students, in choosing applications and using them as a learning tool. (2), Research conducted by [17] entitled the contribution of mathematical resilience to students 'academic abilities in the mathematical statistics course, the results of the study 
showed that there was a positive correlation between mathematical resilience and students' academic abilities, with mathematical resilience contributing $48.5 \%$ of students' academic abilities.

\section{Method}

This research is quantitative research with the type of ex-post-facto research. The population in this study was the mathematical power of all students of the mathematics education study program of UNIKA Santu Paulus Ruteng. The sample will be determined using a simple random sampling technique, namely 77 students combined from level 1 and level 2. Data were collected through tests and questionnaires. Questionnaires are used to collect data on mathematical resilience and perceptions of online lectures, while tests in the form of essay questions totaling five numbers are used to measure students' mathematical power. The data was given to the research sample when it was tested on level 3 students. Furthermore, the data were analyzed using multiple linear regression with the help of the SPPS 15 for the windows program.

\section{Result and Discussion}

The research data was obtained in the form of mathematical resilience data, perceptions of online lectures, and mathematical power of students of the mathematics education study program of Unika Santu Paulus Ruteng in the academic year 2020/2021. The data were obtained using questionnaires and tests. research results and discussion related to the findings in research. The following is a presentation of research data which includes the results of filling out a questionnaire to determine mathematical resilience and perceptions of online learning, as well as the results of mathematical power tests.

Table 1. Data on mathematical resilience and perceptions of online lectures

\begin{tabular}{cccc}
\hline & $\begin{array}{c}\text { Mathematical } \\
\text { Resilience }\end{array}$ & $\begin{array}{c}\text { perceptions of } \\
\text { online lectures }\end{array}$ & Mathematical Power \\
\hline $\begin{array}{c}\text { Average } \\
\text { The } \\
\text { highest } \\
\text { score } \\
\text { Lowest } \\
\text { score }\end{array}$ & 60,74 & 67,40 & 67,00 \\
\hline
\end{tabular}

Before testing the hypothesis, the researcher must first know the prerequisite test results. The prerequisite test must be the key to determining the type of statistical test used in testing the hypothesis. There are also prerequisite tests that were fulfilled in this study, namely the normality test, linearity test, and multicollinearity test. Data calculations were performed with the help of the SPSS 15 for the windows program. 
Table 2. Normality Test Results

\begin{tabular}{cccc}
\hline & $\alpha$ & Sig & Description \\
\hline $\begin{array}{c}\text { Unstandardi zed } \\
\text { Residual }\end{array}$ & 0,05 & 0,200 & residual data \\
normally distributed
\end{tabular}

Based on the presentation of data in table 2 with a significant value $>0.05$, the residual data is normally distributed.

Table 3. Linearity Test Results

\begin{tabular}{cccc}
\hline Variable & $\alpha$ & Sig & Informations \\
\hline $\begin{array}{c}\text { Mathematical } \\
\text { Resilience }\end{array}$ & 0,05 & 0,488 & $\begin{array}{c}\text { Mathematical } \\
\text { resilience and } \\
\text { mathematical power } \\
\text { were linear } \\
\text { Preception of } \\
\text { Online }\end{array}$ \\
Lectures & 0,05 & 0,412 & $\begin{array}{c}\text { Perceptions of } \\
\text { online lectures and } \\
\text { mathematical power } \\
\text { were linear. }\end{array}$ \\
\hline
\end{tabular}

Based on the presentation of data in table 3 with a significance $>0.005$, there is a linear relationship between mathematical resilience toward mathematical power and perceptions of online lectures toward mathematical power.

Table 4. Multicollinearity Test Results

\begin{tabular}{|c|c|c|}
\hline \multirow{2}{*}{ Model } & \multicolumn{2}{|c|}{ Collinearity Statistics } \\
\hline & Tolerance & VIF \\
\hline Mathematical Resilience & 0,690 & 1,450 \\
\hline $\begin{array}{l}\text { Preception of Online } \\
\text { Lectures }\end{array}$ & 0,690 & 1,450 \\
\hline
\end{tabular}

Based on the data presentation in table 4 with a VIF value $<10$ and a tolerance value $>$ 0.1 , it can be concluded that there is no multicollinearity in the regression. Thus, it can be concluded that there is no multicollinearity in the regression.

Table 5. Results of Multiple Linear Regression Analysis

\begin{tabular}{ccc}
\hline & \multicolumn{2}{c}{ Unstandardized Coefficients } \\
\cline { 2 - 3 } Model & $\mathrm{B}$ & Std. Error \\
\hline (Constant) & 20,322 & 4,514 \\
Mathematical Resilience & 0,498 & 0,066 \\
Preception of Online Lectures & 0,227 & 0,071 \\
\hline
\end{tabular}

Based on the data presented in table 5 , it is obtained for the independent variables $\mathrm{X} 1=$ 0.498 and $\mathrm{X} 2=0.227$ with a constant of 20.322 , so that the regression equation model obtained is: $\mathrm{Y}=20,322+0,498 \mathrm{X} 1+0,227 \mathrm{X} 2$. 
Table 6. Simultaneous determination coefficient test

\begin{tabular}{cccc}
\hline Model & $\mathrm{R}$ & $\mathrm{R}$ Square & Adjusted $R$ Square \\
\hline 1 & $0,806(\mathrm{a})$ & 0,648 & 0,640 \\
\hline
\end{tabular}

Based on the data presented in table 6 , the simultaneous coefficient of determination was 0.648. This shows that the variation of changes in mathematical power is influenced by changes in mathematical resilience and perceptions of online lectures by $64.8 \%$.

Table 7. Results of t test analysis

\begin{tabular}{ccc}
\hline & $\alpha$ & Sig. \\
\cline { 2 - 3 } Mathematical Resilience & 0,05 & 0,000 \\
Perceptions of Online Lectures & 0,05 & 0,000 \\
\hline
\end{tabular}

Based on table 7 , a significant value $<0.05$, it can be said that partially mathematical resilience has a significant effect on mathematical power. Furthermore, it can also be said that partially perceptions of online lectures have a significant effect on mathematical power.

\section{Conclusion}

The results of hypothesis testing show that mathematical resilience and perceptions of online lectures affect mathematical power. Mathematical power includes several aspects, namely problem solving, mathematical communication, mathematical connections, and mathematical reasoning. Therefore, whether or not students' mathematical resilience greatly affects their mathematical power during the Covid-19 pandemic. This is because mathematical resilience is one of the internal factors that can affect success in learning mathematics [18] [19]. In line with that, resilience is a positive attitude that can make students not easily give up when having difficulty solving math problems through discussions and investigations about mathematics [20].

In addition, academically resilient students will display responses both cognitive, affective, and psychomotor [21]. In the context of online learning, this capacity will help individuals to be better prepared to take part in online learning, which can be seen from the extent to which students believe they have the abilities and skills needed in online learning [22]. This is in line with research conducted by [23] show that students who have high resilience turn out to be able to solve mathematical problems well, while students who have low resilience are less precise in solving mathematical problems.

Students who have strong resilience besides being able to answer questions well on exams, also have other math skills needed and are willing to apply them in everyday life if needed [4]. They consider mathematics learning is not an obstacle, even when students experience difficulties, they will maintain their confidence until success. In undergoing online lectures, one of the internal factors that can affect students' mathematical power is the student's perception of the online lecture. Students 'positive perceptions regarding the 
implementation of online lectures related to the teaching and learning process, aspects of lecturer capabilities, and practical suggestions can have a positive effect on some of the student's mathematical abilities [5]. Thus, partially and simultaneously mathematical resilience and mathematical perceptions affect the mathematical power of students.

\section{Acknowledgements}

Researchers would like to thank the institution and students of UNIKA Santu Paulus Ruteng who have helped researchers in the success of this research.

\section{References}

[1] S. P. Sari, J. E. Aryansah, and K. Sari, "Resiliensi mahasiswa dalam menghadapi pandemi covid 19 dan implikasinya terhadap proses pembelajaran," Indonesian Journal of Guidance and Counseling : Theory and Application. 2020.

[2] L. S. Zanthy, "Kontribusi Resiliensi Matematis Terhadap Kemampuan Akademik Mahasiswa Pada Mata Kuliah Statistika Matematika," Mosharafa J. Pendidik. Mat., vol. 7, no. 1, pp. 85-94, 2018, doi: 10.31980/mosharafa.v7i1.344.

[3] M. T. Priyastuti and S. Suhadi, "Kepuasaan Mahasiswa terhadap Pembelajaran Daring Selama Pandemi Covid-19,” J. Lang. Heal., vol. 1, no. 2, pp. 49-56, 2020, doi: 10.37287/jlh.v1i2.383.

[4] E. Komala, "Mathematical Resilience Mahasiswa Pada Mata Kuliah Struktur Aljabar I Menggunakan Pendekatan Explisit Instruction Integrasi Peer Instruction," Mosharafa J. Pendidik. Mat., vol. 6, no. 3, pp. 357-364, 2018, doi: 10.31980/mosharafa.v6i3.324.

[5] M. I. Mustofa, M. Chodzirin, and L. Sayekti, "Formulasi Model Perkuliahan Daring Sebagai Upaya Menekan Disparitas Kualitas Perguruan Tinggi (Studi terhadap Website pditt.belajar.kemdikbud.go.id)," Walisongo J. Inf. Technol., vol. 1, no. 2, pp. 151-160, 2019.

[6] Karlimah, "Pengembangan Kemampuan Komunikasi dan Pemecahan masalah serta Disposisi Matematis Mahasiswa PGSD melalui Pembelajaran Berbasis Masalah,” Pendidikan, vol. 11, no. 4, pp. 51-60, 2010.

[7] P. Nurfauziah and N. F. Fitriani, "Gender Dan Resiliensi Matematis Siswa Smp Dalam Pembelajaran Scientific Berbantuan Vba Excel,” Symmetry Pas. J. Res. Math. Learn. Educ., vol. 4, pp. 28-37, 2019, doi: 10.23969/symmetry.v4i1.1633.

[8] R. P. Veras, “No Title طرق تدريس اللغة العربية," Экономика Региона, no. 3, p. 32, 2012.

[9] J. P. Islam et al., "Jurnal An- nida'," vol. 41, no. 2, 2017.

[10] L. Anhusadar, "Persepsi Mahasiswa PIAUD terhadap Kuliah Online di Masa Pandemi Covid 19," KINDERGARTEN J. Islam. Early Child. Educ., vol. 3, no. 1, p. 44, 2020, doi: 10.24014/kjiece.v3i1.9609.

[11] C. Dziuban, C. R. Graham, P. D. Moskal, A. Norberg, and N. Sicilia, "Blended learning: the new normal and emerging technologies," Int. J. Educ. Technol. High. Educ., vol. 15, no. 1, pp. 1-16, 2018, doi: 10.1186/s41239-017-0087-5.

[12] W. Tao, "The Importance of Mathematical Model in Mathematics Learning," Theor. Math. Study, vol. 2, no. 2, pp. 66-70, 2002, doi: 10.35534/tms.0202010c.

[13] O. Omoniyi Israel and O. Peter Olubunmi, "An Appraisal of Sciences and Mathematics Dyslexia and Dyscalculia Syndrome among Secondary Schools Students," Am. J. Educ. Res., vol. 2, no. 4, pp. 219-224, 2014, doi: 10.12691/education-2-4-7.

[14] Anim and Mapilindo, "Persepsi Mahasiswa Pendidikan Matematika Tentang Pembelajaran Daring Selama Masa Learn From Home (Lfh) Pandemic Covid-19,” Mat. Paedagog., vol. 5, no. 1, pp. $72-$ 80, 2020, [Online]. Available: http://jurnal.una.ac.id/index.php/jmp/article/view/1449.

[15] W. Hidayat, I. Herdiman, U. Aripin, A. Yuliani, and R. Maya, "Adversity Quotient (AQ) dan Penalaran Kreatif Matematis Mahasiswa Calon Guru," J. Elem., vol. 4, no. 2, p. 230, 2018, doi: 10.29408/jel.v4i2.701.

[16] K. Kabuto, K. Sasaki, and Y. Sasaki, "Absolute configuration of aldonic acids and lanthanoid induced shift by the chiral shift reagent propylenediaminetetraacetatoeuropium(III) in aqueous 
solution," Tetrahedron: Asymmetry, vol. 3, no. 11, pp. 1357-1360, 1992, doi: 10.1016/09574166(92)80005-H.

[17] M. Hafiz, Darhim, and J. A. Dahlan, "Comparison of Mathematical Resilience among Students with Problem Based Learning and Guided Discovery Learning Model,” J. Phys. Conf. Ser., vol. 895, no. 1, 2017, doi: 10.1088/1742-6596/895/1/012098.

[18] S. Cassidy, "The Academic Resilience Scale (ARS-30): A new multidimensional construct measure," Front. Psychol., vol. 7, no. NOV, pp. 0-11, 2016, doi: 10.3389/fpsyg.2016.01787.

[19] Ö. Coşkun, V. Özeke, I. Budakoğlu, and S. Kula, "E-learning readiness of Turkish medical students: A sample from Gazi University," Gazi Med. J., vol. 29, no. 4, pp. 340-345, 2018, doi: 10.12996/gmj.2018.91.

[20] H. I. Kurnia, Y. Royani, H. Hendiana, and P. Nurfauziah, "Analisis Kemampuan Komunikasi Matematik Siswa Smp Di Tinjau Dari Resiliensi Matematik,” J. Pembelajaran Mat. Inov., vol. 1, no. 5, pp. 933-940, 2018, [Online]. Available: https://journal.ikipsiliwangi.ac.id/index.php/jpmi/article/view/1597/288. 